\title{
Effect of soil chiseling on soil structure and root growth for a clayey soil under no-tillage
}

\author{
Márcio Renato Nunes ${ }^{\mathrm{a}, *}$, José Eloir Denardin ${ }^{\mathrm{b}}$, Eloy Antônio Pauletto ${ }^{\mathrm{c}}$, \\ Antônio Faganello ${ }^{\mathrm{b}}$, Luiz Fernando Spinelli Pinto ${ }^{\mathrm{c}}$ \\ a University of São Paulo, "Luiz de Queiroz" College of Agriculture, Avenida Pádua Dias, 11, CEP 13418-900 Piracicaba, São Paulo, Brazil

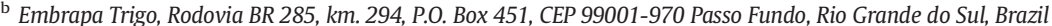 \\ ${ }^{c}$ Federal University of Pelotas, Department of Soil Science, Campus Universitário s/n, P.O. Box 354, 96010-900 Pelotas, Rio Grande do Sul, Brazil
}

\section{A R T I C L E I N F O}

\section{Article history:}

Received 11 November 2014

Received in revised form 2 June 2015

Accepted 3 June 2015

Available online $\mathrm{xxxx}$

\section{Keywords:}

Soil physical attributes

Soil compaction

Root growth

Organic carbon

Soil structure

\begin{abstract}
A B S T R A C T
Soil chiseling under no-tillage (NT) promotes root growth in depth. This practice, however, might affect soil aggregation. This study evaluated the chiseling effects on the aggregation of a Ferralic Nitisol (Rhodic), under NT, in humid subtropical climate region. The treatments carried out consisted of the time that soil was kept under NT after chiseling: continuous NT for 24 months after chiseling in September 2009; continuous NT for 18 months after chiseling in March 2010; continuous NT for 12 months after chiseling in September 2010; continuous NT for 6 months after chiseling in March 2011; NT in newly chiseling soil in September 2011; continuous NT without chiseling (control). The species cultivated in the area were: corn in 2009/2010 growing season; wheat in 2010; soybean in 2010/2011 growing season; rye in 2011; and corn in 2011/2012 growing season. Treatment effects were evaluated through the following determinations: soil organic carbon, aggregates stability, mean weight diameter, aggregates larger than $2 \mathrm{~mm}$, and soil macroaggregates and microaggregates. The corn root density was correlated to the soil aggregation parameters. The effect of soil chiseling, in a clayey humid subtropical soil under $\mathrm{NT}$, reduced the size of soil aggregates, in the layer 0.07 to $0.17 \mathrm{~m}$, in the first six months after this practice. However, 12 months after the soil chiseling, the aggregates returned to the original size. Root growth was favored in the layer between 0.07 and $0.20 \mathrm{~m}$, due to the chisel action, and did not influence soil aggregation in relation to the control treatment. The soil chiseling practice, therefore, did not promote persistent improvement in the structure of a clayey soil under NT, in humid subtropical climate region.
\end{abstract}

(c) 2015 Elsevier B.V. All rights reserved.

\section{Introduction}

The no-tillage (NT) is adopted in more than 100 million ha in the world (Derpsch et al., 2010). This is a system in which crops are sown without any prior loosening of the soil by cultivation other than the very shallow disturbance (about at $0.05 \mathrm{~m}$ ) which may arise by the passage of the drill coulters and after which usually $30-100 \%$ of the surface remains covered with plant residues (Soane et al., 2012). The adoption of NT may result in economic and environmental benefits (Lal et al., 1999; Shaver et al., 2003; Adl et al., 2005; Putte et al., 2010; Babujia et al., 2010; Silva et al., 2014). However, the clayey soils under NT typically show a compacted layer, at around 0.07 and 0.20 m deep (Reichert et al., 2009; Nunes et al., 2015). This concentrates the crop root system in the topsoil layer, at around 0 to $0.07 \mathrm{~m}$ (Nunes et al., 2015), affecting water and nutrient uptake by crops (Batey and McKenzie, 2006) and,

\footnotetext{
* Corresponding author.

E-mail addresses: marcio_r_@yahoo.com.br (M.R. Nunes), denardin@cnpt.embrapa.br (J.E. Denardin), pauletto@ufpel.edu.br (E.A. Pauletto), afaganel@cnpt.embrapa.br (A. Faganello), lfspin@ufpel.edu.br (L.F.S. Pinto).
}

consequently, decreases crop yield (Buttery et al., 1998; Hamza and Anderson, 2005).

Mechanical chiseling has been used to disrupt the compacted layer of soils under NT system. This practice increases soil porosity, decreases soil bulk density and promotes root development (Colonego and Rosolem, 2010; Nunes et al., 2014). The root system has direct effect on the soil aggregation state (Martins et al., 2009), and is the main source of organic carbon accumulation in the soil (Santos et al., 2011). This can improve soil aggregation (Colonego and Rosolem, 2008). However, the soil chiseling effects might disappear after, approximately, two years of operation, depending on soil texture, climate, and cropping system (Evans et al., 1996; Colonego and Rosolem, 2010; Nunes et al., 2014). On other hand, increase of soil organic carbon content is a slow process (Six et al., 2002; Abdollahi et al., 2014), and the positive effects due to plant species growth on soil aggregates under NT are expected to occur in the long-term (Garcia et al., 2013).

Soil mechanical chiseling, per se, should not have great impact on the soil organic matter and soil aggregation. However, the increases of aeration and temperature in the topsoil layer (at around $0-0.25 \mathrm{~m}$ ), due to soil mechanical chiseling, might accelerate organic carbon 
mineralization and, consequently, influence soil aggregation state (Fabrizzi et al., 2009). Soil biological and biochemical properties respond quickly to changes produced by soil management (Visser and Parkinson, 1992; Trasar-Cepeda et al., 2008; Garcia et al., 2013). According to Melero et al. (2011), mechanical practice to mitigate soil compaction under NT has a negative effect on organic carbon and on enzymatic activities, producing, in short-term, losses in organic matter, reducing soil biochemical quality. Furthermore, the chisel mechanical action might break soil aggregates, decreasing their size similarly to the soil preparation with plow and harrow disk (Fabrizzi et al., 2009), which initially reduces macro-aggregates percentage (Colonego and Rosolem, 2008). Therefore, the mechanical chiseling on soil under NT may have negative effects; decreasing soil organic carbon level and reducing the soil aggregates size and stability.

Mechanical chiseling is not only costly, but also is a practice that opposes the NT system precepts, since it involves intense disturbance of soil, greater traffic of machinery, additional use of agricultural implements in crops, and increased cost of production (Bertolini and Gamero, 2010). Therefore, it is important to conduct an assessment of its effects on the soil aggregation state, as well as on the persistence of these effects to remedy restrictions on root growth in areas under NT system.

This study was developed based on the following hypothesis: i) soil chiseling decrease soil aggregates size and stability in areas under NT; ii) improved root growth by chiseling is not sufficient to promote improvement in the clay soil aggregation condition in the compacted layer in areas under NT system; iii) soil chiseling does not promote longlasting improvement in the clay soil structure in areas under NT system. Therefore, the purpose of the this study was to evaluate the soil mechanical chiseling effect on the soil aggregation state and on the organic carbon level of a clayey soil [Ferralic Nitisol (Rhodic)] managed under NT system.

\section{Material and methods}

\subsection{Experimental design and area}

The study was carried out at Embrapa Trigo Experimental Field, in Passo Fundo, Rio Grande do Sul, Brazil (28 $11^{\prime} 20^{\prime \prime}$ S; 52 ${ }^{\circ} 19^{\prime} 62^{\prime \prime}$ W; $691 \mathrm{~m}$ altitude) in a Ferralic Nitisol (Rhodic) (USDA, 2012) with clayey texture (Table 1 ), and located in a gently rolling relief. The climate in the region, according to the Köppen classification, is Cfa, humid subtropical.

The experimental area has been cultivated under NT for over 10 years, in a crop production model comprised by the succession of soybean and corn (Zea mays L.) in summer and wheat (Triticum aestivum L.) in winter. The soil in this area clearly presented a compacted layer between 0.07 and $0.20 \mathrm{~m}$ depth, revealed in an expeditious evaluation performed in the field by the method of the cultural profile (Silva et al., 2014).

The experiment started in September 2009, in randomized blocks, with four replications and six treatments, resulting in 24 plots with dimensions of $8 \times 6 \mathrm{~m}$ each. The treatments consisted of the time the soil was kept under NT, after the mechanical chiseling operation: C24, continuous NT for 24 months, after chiseling carried out in September 2009; C18, continuous NT for 18 months, after chiseling carried out in March 2010; C12 continuous NT for 12 months, after chiseling carried out in September 2010; C6, continuous NT for 6 months, after chiseling carried out

Table 1

Physical characterization of the Ferralic Nitisol (Rhodic), used in the study.

\begin{tabular}{|c|c|c|c|c|c|}
\hline \multirow{2}{*}{$\frac{\text { Layer }}{(\mathrm{m})}$} & Clay & Silt & Sand & $\mathrm{DC}$ & \multirow{2}{*}{$\frac{P D}{\left(\mathrm{~g} \mathrm{~cm}^{-3}\right)}$} \\
\hline & \multicolumn{4}{|c|}{$\left(\mathrm{g} \mathrm{kg}^{-1}\right)$} & \\
\hline $0.00-0.07$ & 587 & 203 & 210 & 316 & 2.67 \\
\hline $0.07-0.17$ & 601 & 193 & 206 & 397 & 2.72 \\
\hline $0.17-0.20$ & 604 & 194 & 202 & 408 & 2.74 \\
\hline $0.20-0.30$ & 630 & 188 & 182 & 425 & 2.74 \\
\hline
\end{tabular}

$\mathrm{DC}=$ dispersed clay. $\mathrm{PD}=$ particle density. in March 2011; C0, NT in recently chiseled soil, in September 2011; NT, continuous NT, without chiseling (control). The effect of these treatments was evaluated during the 2011/12 cropping season.

During the study (2009 to 2012), machinery traffic in the experimental area was restricted to the crop sowing and mechanical chiseling operation. The crops were sown with a seeder equipped with drill coulters, in order to produce the furrow and also to inject fertilizer at $0.05 \mathrm{~m}$ and $0.07 \mathrm{~m}$ depth for winter and summer crops, respectively, similarly the depth of action of soil openers typically employed in the subtropical humid climate region in Brazil. The weight of this seed drill was approximately $2800 \mathrm{~kg}$, while the weight of the tractor used to pull the seed drill and the chisel plow was around $5000 \mathrm{~kg}$.

The species cultivated throughout the period of the experiment that was conducted from September 2009 to February 2012, were: corn, from September 2009 to February 2010; wheat, from June 2010 to November 2010; soybean, from November 2010 to March 2011; rye (Secale cereale L.), from April 2011 to September 2011; and corn, from September 2011 to February 2012 (Table 2).

Soil mechanical chiseling reached a depth of approximately $0.25 \mathrm{~m}$, with a chisel plow equipped with five fixed shanks, $0.30 \mathrm{~m}$ interval between the shanks, and roller, which makes harrowing unnecessary (Fig. 1). The width of the shanks was $60 \mathrm{~mm}$. The operation was carried out while the soil presented water content close to the friability point.

\subsection{Soil sampling and analyses}

The plant root system was evaluated, in December 2011, in the corn R3 phenological stage (Ritchie and Hanway, 1993), through the nailplate technique (Bohm, 1979). The nail-plate used was $0.60 \mathrm{~m}$ wide, $0.30 \mathrm{~m}$ high and $0.05 \mathrm{~m}$ thick, resulting in the collection of soil and root monolith with $9 \mathrm{dm}^{3}$. After dispersion and soil removal from the monoliths, the root system present in each monolith was divided into three layers: 0 to $0.07 \mathrm{~m} ; 0.07$ to $0.17 \mathrm{~m}$; and 0.17 to $0.30 \mathrm{~m}$. The roots contained in each layer were dried in oven at $65^{\circ} \mathrm{C}$, for $72 \mathrm{~h}$, and the dry matter mass was evaluated in a $0.0001 \mathrm{~g}$ precision scale. The root density, in kilograms per soil cubic meter, was estimated through ratio between the root dry matter mass and the soil volume in each layer.

In February 2012, after the corn was harvested, in the experimental units corresponding only to control treatment (NT), pits $0.30 \mathrm{~m}$ deep were opened transversally to the soil chisel action, to allow expeditious evaluation by the cultural profile method (Silva et al., 2014). The soil, in the control plots, clearly presented three distinct layers: i) surface layer, at around $0.0-0.07 \mathrm{~m}$, characterized by soil with aggregates of varied sizes and pores visible to the naked eye; ii) compacted layer, at around $0.07-0.20 \mathrm{~m}$, characterized by massive soil structure, and without pores visible to the naked eye; iii) layer between 0.20 and $0.30 \mathrm{~m}$, apparently

Table 2

Treatments indication and species grown throughout the period the experiment was conducted.

\begin{tabular}{llllll}
\hline \multirow{2}{*}{ Treatments } & Summer & Winter & Summer & Winter & Summer \\
& 2009-2010 & 2010 & 2010-2011 & 2011 & 2011-2012 \\
\hline C24 & Chiseling & NT & NT & NT & NT \\
& Corn & Wheat & Soybean & Rye & Corn \\
C18 & NT & Chiseling & NT & NT & NT \\
& Corn & Wheat & Soybean & Rye & Corn \\
C12 & NT & NT & Chiseling & NT & NT \\
& Corn & Wheat & Soybean & Rye & Corn \\
C6 & NT & NT & NT & Chiseling & NT \\
& Corn & Wheat & Soybean & Rye & Corn \\
C0 & NT & NT & NT & NT & Chiseling \\
& Corn & Wheat & Soybean & Rye & Corn \\
Control & NT & NT & NT & NT & NT \\
& Corn & Wheat & Soybean & Rye & Corn \\
\hline
\end{tabular}

C24: continuous No-Till (NT) for 24 months, after chiseling; C18: continuous NT for 18 months, after chiseling; C12: continuous NT for 12 months, after chiseling; C6: continuous NT for 6 months, after chiseling; C0: NT in newly chiseling soil; Control: continuous NT, without chiseling. 


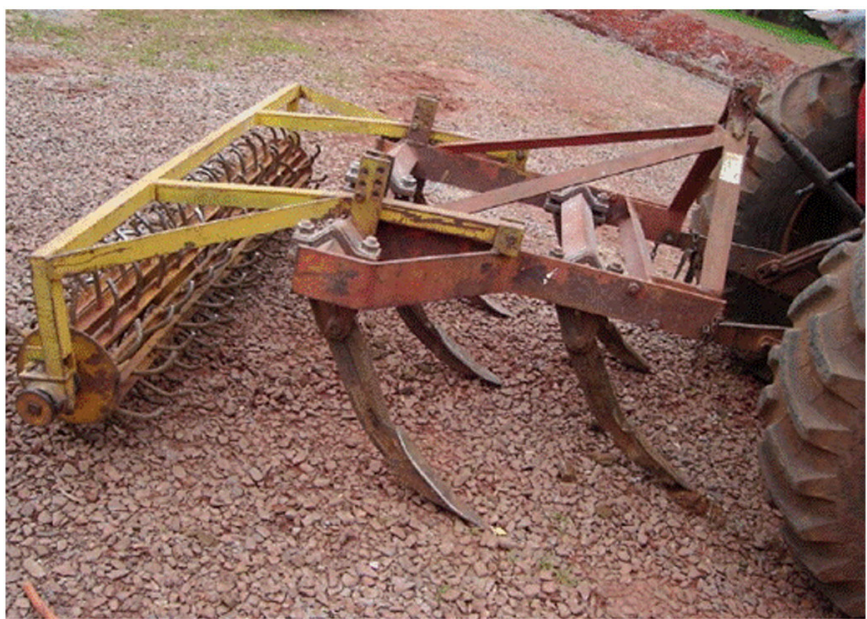

Fig. 1. Chiseling plow, used in the soil mechanical chiseling, equipped with five fixed shanks $0.30 \mathrm{~m}$ interval between the shanks, and roller, which makes harrowing unnecessary. Adapted from Drescher (2011).

less compacted, and showing the natural soil structure. Based on this field evaluation, in the $0.02-0.05 \mathrm{~m}$ (layer i), $0.09-0.012$ and at $0.17-0.20 \mathrm{~m}$ (layer ii) and 0.25-0.28 (layer iii), six undisturbed soil samples, in each layer, were collected in stainless cylinders with $48 \mathrm{~mm}$ diameter and $30 \mathrm{~mm}$ height. Similar $0.30 \mathrm{~m}$ deep pits were opened in the remaining experimental units to collect the soil samples, following the same layers and procedures used for the control treatments.

Three of these samples were used to determine soil macroporosity ( $\varnothing>0.05 \mathrm{~mm}$ ) through the method described by Embrapa (2011) and soil bulk density through the method described by Grossman and Reinsch (2002). The other three samples were used to determine the soil penetration resistance with a bench-mounted electronic penetrometer, model MA 933, brand Marconi, equipped with an electronic speed variator, data register system and cone with $30^{\circ}$ semi-angle and $3 \mathrm{~mm}$ diameter. The penetration speed was $10 \mathrm{~mm} \mathrm{~min}^{-1}$. The determination of soil penetration resistance was processed in the samples with water tension balanced at $10 \mathrm{kPa}$. The soil penetration resistance reading obtained from the upper ( $3 \mathrm{~mm}$ ) and the lower $(3 \mathrm{~mm})$ parts of the samples were disregarded, only taking into consideration the readings of the $24 \mathrm{~mm}$ center of each sample.

In the $0.30 \mathrm{~m}$ deep pits, in the same layers (i, ii, and iii), disturbed samples were collected. In the laboratory, these samples were dried in shade until they reached the humidity corresponding to the friability point. Next, they were sieved in a $9.52 \mathrm{~mm}$ mesh sieve, breaking aggregates larger than $9.52 \mathrm{~mm}$ in their weak plans. Later on, a part of the sample was sieved in a $2 \mathrm{~mm}$ mesh sieve to determine particle size, water dispersed clay (Gee and Or, 2002) and the soil organic carbon through the Walkley-Black method. The remaining sample was used to quantify the water stability of aggregates, adapted from the method described by Kemper and Chepil (1965), using the Yoder (1936) vertical oscillation machine. Each sample of air dried soil was homogenized and then divided into four subsamples uniformly distributed aggregates. Three of these were used for wet stability measurements and one for water content assessment. Thus, the wet stability tests had three replicates per plot depth.

In the Yoder machine, $50.00 \mathrm{~g}$ dry weight based samples were put on a filter paper previously adapted to the upper sieve of a sieve set with $4.76 ; 2.0 ; 1.0 ; 0.25$ and $0.105 \mathrm{~mm}$ meshes. The filter paper aimed to avoid the material distribution to the sieves prior to the water saturation. The sieve set was then regulated so that the water level reached the lower part of the sample put in the largest diameter sieve and has ensured sample wetting through capillarity. The sample was kept in this position for $10 \mathrm{~min}$. After this time, the filter paper was removed and the sample sieving was carried out for $10 \mathrm{~min}$, with the machine regulated to carry out 36 vertical oscillations in a $0.035 \mathrm{~m}$ per minute route. Following this procedure, the aggregates were distributed on the sieves according to their stability and size. This material was transferred to aluminum capsules and dried in oven at $105{ }^{\circ} \mathrm{C}$ for a period of $24 \mathrm{~h}$ and weighed in precision scales. After that, it was submersed in $1 \mathrm{~mol} \mathrm{~L}^{-1}$ at $6 \%$ sodium hydroxide solution for one night. Next, the material was washed using the same sieve where it had been generated, and after drying in oven the inert material was obtained (gravel, sand, roots, crop residues).

In order to calculate the water-stable aggregate percentage in different size classes $(\mathrm{C} 1=9.52-4.76 \mathrm{~mm}$; $\mathrm{C} 2=4.76-2.0 \mathrm{~mm}$; $\mathrm{C} 3=2.0-1.0 \mathrm{~mm} ; \mathrm{C} 4=1.0-0.25 \mathrm{~mm} ; \mathrm{C} 5=0.25-0.105 \mathrm{~mm}$ and $\mathrm{C} 6 \leq 0.105 \mathrm{~mm}$ ), and the mean weight diameter (MWD) of the aggregates, the expressions (1) and (2), respectively, were employed. The aggregates were also separated into: aggregates larger than $2 \mathrm{~mm}(\mathrm{~A}>2 \mathrm{~mm})$; macro- $(>0.25 \mathrm{~mm})$ and microaggregates $(<0.25 \mathrm{~mm})$, according to Tisdall and Oades (1982).

$$
\begin{aligned}
& \text { AGRi }=\left[\frac{(\text { MAGRi }- \text { mi })}{\sum_{\mathrm{i}=1}^{\mathrm{n}}(\text { MAGRi }-\mathrm{mi})}\right] \cdot 100 \\
& \mathrm{MWD}=\left[\frac{\left.\sum_{\mathrm{i}=1}^{\mathrm{n}} \text { DMi (MAGRi }-\mathrm{mi}\right)}{\sum_{\mathrm{i}=1}^{\mathrm{n}}(\mathrm{MAGRi}-\mathrm{mi})}\right]
\end{aligned}
$$

where AGRi is the proportion of water stable aggregates in a specific class (i), MAGRi is the aggregate mass plus class i inert material, mi is the inert material mass (gravel, sand, roots, crop residues) in class $i$, and $\mathrm{DMi}$, is the mean diameter in class $\mathrm{i}(\mathrm{mm})$.

\subsection{Statistical analysis}

The effect of treatments on the properties under evaluation was analyzed through the variance analysis and differences between treatment means were considered statistically significant at $\mathrm{p}$ value $<0.05$ using the Tukey test, separately, in each soil layer. The distribution of water stable aggregates regarding the size classes was analyzed in relation to the sample standard deviation. The influence of plant root development on the soil aggregation was analyzed through correlations between the plant root density and the soil physical properties from the layer between 0.07 and $0.17 \mathrm{~m}$.

\section{Results}

In the 0.0 to $0.07 \mathrm{~m}$ and 0.25 to $0.28 \mathrm{~m}$ layers, the soil mechanical chiseling did not affect the soil aggregation state and the soil organic carbon content (Table 3 and Fig. 2). For other hand, in the 0.07 to $0.20 \mathrm{~m}$ layer (ii), normally the compacted soil layer in soil under NT, the mechanical chiseling influenced the soil water-stable aggregates and the soil aggregate size. In this layer, rupture of the soil aggregates occurred, resulting in smaller sized aggregates and lower aggregate stability (Table 3). In the recently chiseled soil (C0), it can be observed that the percentage of aggregates larger than $2 \mathrm{~mm}$ in the 0.07 to $0.17 \mathrm{~m}$ layer, and the percentage of aggregates larger than $4.76 \mathrm{~mm}$ in 0.07 to $0.17 \mathrm{~m}$ and 0.17 to $0.20 \mathrm{~m}$ layers were significantly lower in comparison with the soil in the continuous NT system (control treatment). Thus, it can be stated that in the first crop after soil chiseling, the action of shanks of chisel plow promoted reduction in the size and stability of soil aggregates in the 0.07 to $0.20 \mathrm{~m}$ layer (ii), in clayey soil under NT in humid subtropical climate region.

The negative effect of soil chiseling on the soil aggregation in the soil subsurface layer, however, is only observed in the first crop after this practice ( $\mathrm{CO})$, as indicated by the reduction in the percentage of aggregates larger than $2 \mathrm{~mm}$ and larger than $4.76 \mathrm{~mm}$ (Table 3 and Fig. 2). 
Table 3

Aggregates larger than $2 \mathrm{~mm}(\mathrm{~A}>2 \mathrm{~mm})$, macro- and microaggregates, mean weight diameter of the aggregates (MWD), organic carbon (OC) and dispersed clay (DC) of a Ferralic Nitisol (Rhodic) as a function of time the soil was kept under no till (NT), after the mechanical chiseling operation.

\begin{tabular}{|c|c|c|c|c|c|c|}
\hline \multirow[t]{2}{*}{ Treatments } & $\mathrm{A}>2 \mathrm{~mm}$ & Macro & Micro & OC & DC & \multirow{2}{*}{$\frac{\text { MWD }}{(\mathrm{mm})}$} \\
\hline & \multicolumn{5}{|l|}{ (\%) } & \\
\hline \multicolumn{7}{|l|}{$0.0-0.07 \mathrm{~m}$} \\
\hline $\mathrm{CO}$ & $44.81 \mathrm{~ns}$ & $90.46 \mathrm{~ns}$ & $9.54 \mathrm{~ns}$ & $1.74 \mathrm{~ns}$ & $34.23 \mathrm{~ns}$ & $3.06 \mathrm{~ns}$ \\
\hline C6 & 48.24 & 91.89 & 8.11 & 1.96 & 31.55 & 3.20 \\
\hline $\mathrm{C} 12$ & 47.22 & 92.04 & 8.00 & 1.94 & 31.03 & 3.02 \\
\hline $\mathrm{C} 18$ & 47.18 & 90.07 & 9.93 & 1.94 & 31.28 & 3.08 \\
\hline $\mathrm{C} 24$ & 44.39 & 87.04 & 12.96 & 1.85 & 31.31 & 3.24 \\
\hline Control & 49.01 & 92.34 & 7.66 & 1.99 & 30.31 & 3.25 \\
\hline $\mathrm{CV} \%$ & 10.17 & 3.78 & 14.68 & 6.23 & 9.21 & 17.44 \\
\hline \multicolumn{7}{|l|}{$0.07-0.17 \mathrm{~m}$} \\
\hline $\mathrm{CO}$ & $42.01 \mathrm{~b}$ & $87.93 \mathrm{~ns}$ & $12.07 \mathrm{~ns}$ & $1.29 \mathrm{~ns}$ & $40.15 \mathrm{~ns}$ & $2.86 \mathrm{~ns}$ \\
\hline C6 & $48.78 \mathrm{a}$ & 92.45 & 7.55 & 1.32 & 38.74 & 3.02 \\
\hline C12 & $46.67 \mathrm{ab}$ & 92.06 & 7.94 & 1.24 & 45.42 & 3.04 \\
\hline C18 & $47.01 \mathrm{ab}$ & 90.82 & 9.18 & 1.27 & 39.30 & 2.88 \\
\hline $\mathrm{C} 24$ & $45.82 \mathrm{ab}$ & 90.57 & 9.43 & 1.26 & 37.80 & 2.83 \\
\hline Control & $51.11 \mathrm{a}$ & 92.13 & 7.87 & 1.24 & 36.65 & 2.96 \\
\hline CV\% & 5.94 & 3.27 & 13.4 & 5.77 & 8.01 & 15.30 \\
\hline \multicolumn{7}{|l|}{$0.17-0.20 \mathrm{~m}$} \\
\hline $\mathrm{CO}$ & $43.46 \mathrm{~ns}$ & $92.08 \mathrm{~ns}$ & $7.92 \mathrm{~ns}$ & $1.25 \mathrm{~ns}$ & $41.58 \mathrm{~ns}$ & $2.79 \mathrm{~ns}$ \\
\hline C6 & 43.35 & 92.12 & 7.88 & 1.24 & 40.95 & 2.60 \\
\hline $\mathrm{C} 12$ & 47.27 & 87.19 & 12.81 & 1.17 & 42.76 & 2.78 \\
\hline C18 & 47.21 & 88.67 & 11.43 & 1.25 & 44.69 & 2.95 \\
\hline $\mathrm{C} 24$ & 44.35 & 90.37 & 9.63 & 1.24 & 42.03 & 2.85 \\
\hline Control & 47.79 & 93.03 & 6.97 & 1.26 & 38.66 & 3.09 \\
\hline $\mathrm{CV} \%$ & 7.10 & 4.48 & 11.04 & 6.21 & 7.90 & 15.34 \\
\hline \multicolumn{7}{|l|}{$0.20-0.30 \mathrm{~m}$} \\
\hline $\mathrm{CO}$ & 36.69 ns & $90.01 \mathrm{~ns}$ & $9.99 \mathrm{~ns}$ & $1.21 \mathrm{~ns}$ & $41.59 \mathrm{~ns}$ & $2.35 \mathrm{~ns}$ \\
\hline C6 & 37.54 & 89.45 & 10.55 & 1.14 & 40.90 & 2.25 \\
\hline C12 & 36.46 & 86.93 & 13.07 & 1.13 & 44.50 & 2.08 \\
\hline C18 & 34.09 & 85.82 & 14.18 & 1.18 & 45.00 & 2.15 \\
\hline $\mathrm{C} 24$ & 33.62 & 85.85 & 14.15 & 1.21 & 43.75 & 2.08 \\
\hline Control & 38.13 & 88.76 & 11.34 & 1.17 & 43.38 & 2.41 \\
\hline CV\% & 9.47 & 4.39 & 10.32 & 7.55 & 8.38 & 17.50 \\
\hline
\end{tabular}

C24, continuous NT for 24 months, after chiseling; C18, continuous NT for 18 months, after chiseling; C12, continuous NT for 12 months, after chiseling; C6, continuous NT for 6 months, after chiseling; C0, NT in newly chiseling soil; Control, continuous NT, without chiseling. Average values followed by the same letter vertically, do not differ among themselves regarding the Tukey test $(\mathrm{p}<0.05)$.

For the remaining variables under study (mean weight diameter, macroaggregate, microaggregate, water dispersed clay and organic carbon content), and the remaining treatments (C6, C12, C18 and C24), there was no difference when compared to the soil under continuous NT (control).

In the 0.07 and $0.17 \mathrm{~m}$ layer, as expected, the soil mechanical chiseling promoted the reduction in the soil resistance to penetration and soil bulk density and an increase in the soil macroporosity after the first crop in the treatment $\mathrm{CO}$ (Table 4). The better soil physical condition, in this layer (ii), improved a deeper root development of corn plants. In the soil subsurface layer, the root density of corn plants that developed in the two first crops after soil chiseling ( $\mathrm{CO}$ and $\mathrm{C6}$ ) was higher than that of the plants that developed in the soil under continuous NT system (control) (Table 5). In this layer, there was significant correlation between soil bulk density and corn plant root density (Fig. 3a), thus indicating that the better soil physical condition allowed a higher root development in the soil subsurface layer under NT.

The soil mechanical chiseling effect on the soil physical properties and on the corn plant root development continued, respectively, for only three ( $\mathrm{CO}, \mathrm{C6}$, and $\mathrm{C} 12)$ and two ( $\mathrm{C0}$ and $\mathrm{C} 6)$ crops after the mechanical practice (Tables 4 and 5). In the treatments C18 and C24 the positive effect resulting from the mechanical chiseling had already expired, confirming the short term effect of chiseling in clayey soils
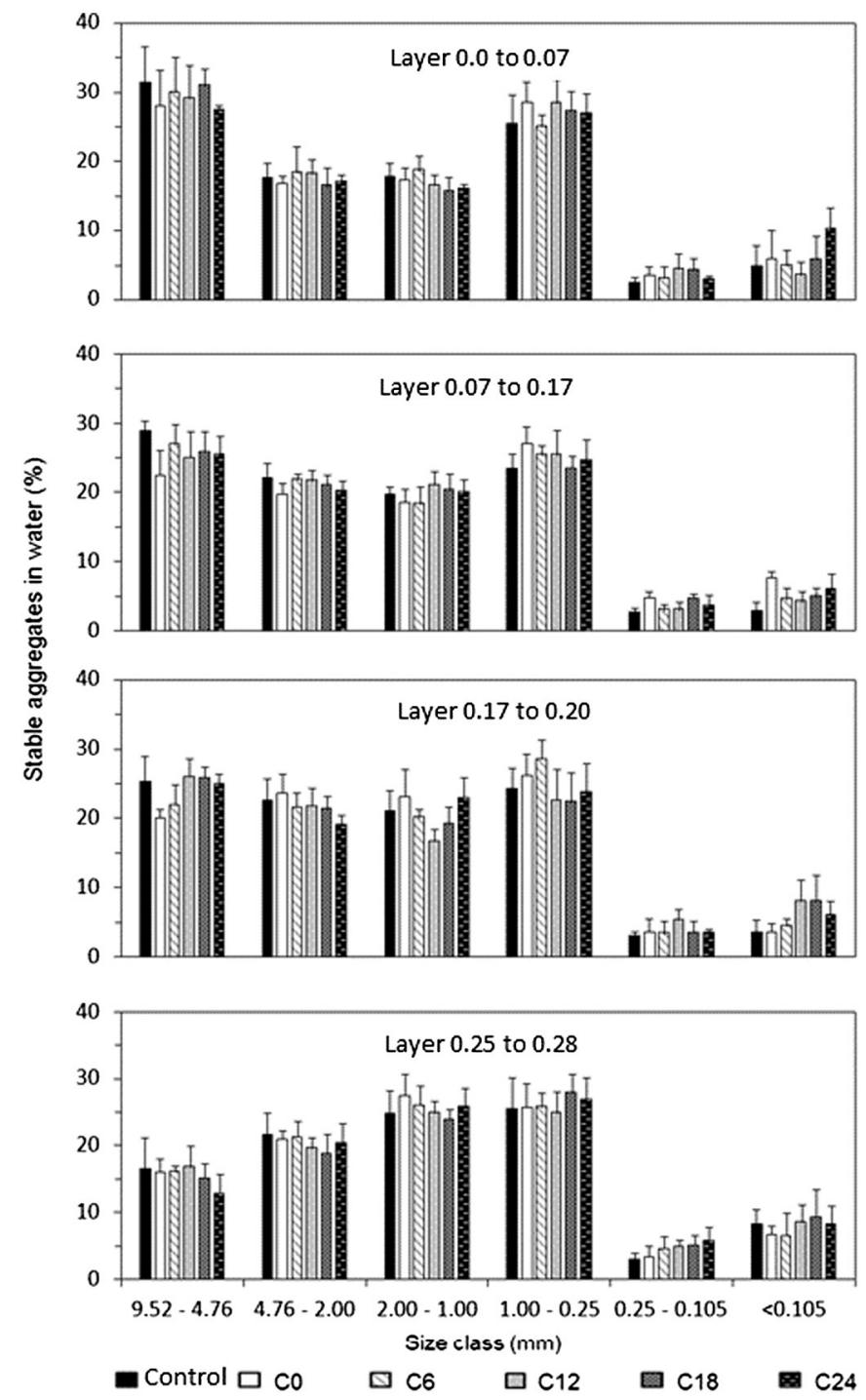

Fig. 2. Distribution of stable aggregates in water regarding the size class of a Ferralic Nitisol (Rhodic). C24, continuous NT for 24 months, after chiseling; C18, continuous NT for 18 months, after chiseling; C12, continuous NT for 12 months, after chiseling; C6, continuous NT for 6 months, after chiseling; C0, NT in newly chiseling soil; Control, continuous NT, without chiseling. Vertical bars represent the standard deviations.

under NT, in humid subtropical climate regions (Evans et al., 1996; Nunes et al., 2014; Silva et al., 2014).

The aggregate wet stability results of the chiseled soils were not better than those observed in the soil under continuous NT system (control), even in the first crop after the mechanical practice (C0, C6, C12), whose root density was higher in comparison with the control treatment (Tables 3, 4 and Fig. 2). The soil bulk density, a soil physical condition indicator, and plant root development, did not have significant correlation with the soil aggregation parameters in the 0.07 to $0.17 \mathrm{~m}$ layer (Fig. 3b, c, d and e).

\section{Discussion}

The soil chiseling not reduces the soil aggregate stability and the soil aggregate size in the surface layer $(0.0-0.07 \mathrm{~m})$ in areas under NT system. The organic matter accumulation (Table 3 ) and the cropping after soil chiseling (Table 2) may have contributed to the not significant soil disaggregation due to the mechanical soil chiseling observed in this layer (Table 3 and Fig. 2). According to Guedes Filho et al. (2013), the mechanical soil chiseling promoted reduction in size and stability of soil aggregates in the layer 0 to $0.05 \mathrm{~m}$ in a Rhodic Hapludox under NT 
Table 4

Physical properties of a Ferralic Nitisol (Rhodic) as a function of time the soil was kept under no till (NT) after the mechanical chiseling operation.

\begin{tabular}{|c|c|c|c|c|c|c|c|}
\hline Layer & $\mathrm{C} 24$ & $\mathrm{C} 18$ & $\mathrm{C} 12$ & C6 & $\mathrm{CO}$ & Control & $\mathrm{CV}(\%)$ \\
\hline$(\mathrm{m})$ & \multicolumn{7}{|c|}{ Soil macroporosity $\left(\mathrm{m}^{3} \mathrm{~m}^{-3}\right)$} \\
\hline $0.00-0.07$ & $0.18 \mathrm{a}$ & $0.18 \mathrm{a}$ & $0.23 \mathrm{a}$ & $0.19 \mathrm{a}$ & $0.20 \mathrm{a}$ & $0.20 \mathrm{a}$ & 26.28 \\
\hline $0.07-0.17$ & $0.10 \mathrm{ab}$ & $0.10 \mathrm{ab}$ & $0.14 \mathrm{ab}$ & $0.15 \mathrm{a}$ & $0.15 \mathrm{a}$ & $0.08 \mathrm{~b}$ & 23.94 \\
\hline $0.17-0.20$ & $0.09 \mathrm{ab}$ & $0.06 \mathrm{~b}$ & $0.09 \mathrm{ab}$ & $0.08 \mathrm{ab}$ & $0.12 \mathrm{a}$ & $0.06 \mathrm{~b}$ & 30.30 \\
\hline \multirow[t]{2}{*}{$0.25-0.28$} & $0.07 \mathrm{a}$ & $0.05 \mathrm{a}$ & $0.05 \mathrm{a}$ & $0.07 \mathrm{a}$ & $0.06 \mathrm{a}$ & $0.06 \mathrm{~b}$ & 25.43 \\
\hline & \multicolumn{7}{|c|}{ Soil bulk density $\left(\mathrm{g} \mathrm{cm}^{-3}\right)$} \\
\hline $0.00-0.07$ & $1.18 \mathrm{a}$ & $1.19 \mathrm{a}$ & $1.05 \mathrm{a}$ & $1.10 \mathrm{a}$ & $1.11 \mathrm{a}$ & $1.06 \mathrm{a}$ & 7.74 \\
\hline $0.07-0.17$ & $1.33 \mathrm{ab}$ & $1.34 \mathrm{ab}$ & 1.24 bc & $1.22 \mathrm{c}$ & $1.20 \mathrm{c}$ & $1.41 \mathrm{a}$ & 3.12 \\
\hline $0.17-0.20$ & $1.35 \mathrm{a}$ & $1.40 \mathrm{a}$ & $1.35 \mathrm{a}$ & $1.34 \mathrm{a}$ & $1.33 \mathrm{a}$ & $1.43 \mathrm{a}$ & 4.61 \\
\hline \multirow[t]{2}{*}{$0.25-0.28$} & $1.35 \mathrm{a}$ & $1.35 \mathrm{a}$ & $1.35 \mathrm{a}$ & $1.28 \mathrm{a}$ & $1.34 \mathrm{a}$ & $1.36 \mathrm{a}$ & 4.15 \\
\hline & \multicolumn{7}{|c|}{ Soil resistance to penetration ( $\mathrm{MPa})$} \\
\hline $0.00-0.07$ & $1.07 \mathrm{a}$ & $1.04 \mathrm{a}$ & $0.92 \mathrm{a}$ & $0.97 \mathrm{a}$ & $1.06 \mathrm{a}$ & $0.97 \mathrm{a}$ & 36.50 \\
\hline $0.07-0.17$ & $2.84 \mathrm{ab}$ & $2.36 a b c$ & $1.89 \mathrm{abc}$ & $1.66 \mathrm{bc}$ & $1.21 \mathrm{c}$ & $3.12 \mathrm{a}$ & 28.39 \\
\hline $0.17-0.20$ & $2.99 \mathrm{~b}$ & $3.16 \mathrm{ab}$ & $3.29 \mathrm{a}$ & $1.95 \mathrm{bc}$ & $1.46 \mathrm{c}$ & $3.24 \mathrm{a}$ & 20.98 \\
\hline $0.25-0.28$ & $2.81 \mathrm{a}$ & $3.19 \mathrm{a}$ & $2.65 \mathrm{a}$ & $2.31 \mathrm{a}$ & $2.36 \mathrm{a}$ & $2.65 \mathrm{a}$ & 10.05 \\
\hline
\end{tabular}

C24, continuous NT for 24 months, after chiseling; C18, continuous NT for 18 months, after chiseling; C12, continuous NT for 12 months, after chiseling; C6, continuous NT for 6 months, after chiseling; CO, NT in newly chiseling soil; Control, continuous NT, without chiseling. Average values followed by the same letter horizontally, do not differ among themselves regarding the Tukey test $(\mathrm{p}<0.05)$.

system. Nevertheless, it can be hypothesized that the shanks of chisel plow can break the soil along the aggregate natural fracture lines, without damaging its natural intra-aggregate structure. If this occurs, the soil mechanical chiseling should not have great impact on the soil aggregation state. According to the results obtained in this study, this can happen to the soil surface layer in areas managed under NT, and furthermore it could be related to the fact that the soil chiseling operation was performed when the soil was in a friable state. According to Baver et al. (1973), this situation favors a less impact on the soil structure by mechanical tillage.

Below the depth of chiseling (0.25-0.28 $\mathrm{m})$ there was as expected no significant effect of chiseling on wet stability and on the soil aggregate size, by soil chiseling, was observed, since the depth of action of shanks of chisel plow was limited to $0.25 \mathrm{~m}$.

In the compacted layer of soil under NT, normally located at around 0.07 to $0.20 \mathrm{~m}$, the negative effect of mechanical chiseling on the soil aggregate size already has been mentioned (Colonego and Rosolem, 2008; Guedes Filho et al., 2013). According to Guedes Filho et al. (2013), in the first six months after soil chiseling in a Rhodic Hapludox under NT system, there was reduction in the soil aggregate size in the layer 0.05 to $0.10 \mathrm{~m}$, due the action of shanks of chisel plow that promoted reduction in the size of soil aggregates. Several studies have showed that mechanical soil preparation has a negative effect on soil aggregation (Al-Kaisi and Yin, 2005; Melero et al., 2011; Portella et al., 2012). In this kind of soil management, the soil structure degradation occurs as a direct effect of the mechanical action of machines used in soil preparation, and as an indirect effect of the soil organic carbon content reduction (Fabrizzi

Table 5

Root dry matter mass of corn plants as a function of time the soil was kept under no till after the mechanical chiseling operation.

\begin{tabular}{|c|c|c|c|c|c|c|c|}
\hline Layer & $\mathrm{C} 24$ & C18 & $\mathrm{C} 12$ & C6 & $\mathrm{CO}$ & Control & $\mathrm{CV}$ \\
\hline$(\mathrm{m})$ & $\left(\mathrm{kg} \mathrm{m}^{-3}\right)$ & & & & & & $(\%)$ \\
\hline $0.00-0.07$ & $4.287 \mathrm{a}$ & $4.311 \mathrm{a}$ & $3.662 \mathrm{a}$ & $3.882 \mathrm{a}$ & $4.262 \mathrm{a}$ & $3.580 \mathrm{a}$ & 8.19 \\
\hline $0.07-0.17$ & $0.710 \mathrm{c}$ & $0.710 \mathrm{c}$ & $0.830 \mathrm{bc}$ & $0.980 \mathrm{ab}$ & $1.120 \mathrm{a}$ & $0.700 \mathrm{c}$ & 7.92 \\
\hline $0.17-0.20$ & $0.210 \mathrm{a}$ & $0.230 \mathrm{a}$ & $0.250 \mathrm{a}$ & $0.220 \mathrm{a}$ & $0.270 \mathrm{a}$ & $0.200 \mathrm{a}$ & 30.38 \\
\hline Total & $1.070 \mathrm{bc}$ & $1.100 \mathrm{~b}$ & $1.040 \mathrm{bc}$ & $1.130 \mathrm{~b}$ & $1.270 \mathrm{a}$ & $0.980 \mathrm{c}$ & 4.35 \\
\hline
\end{tabular}

C24, continuous NT for 24 months after chiseling; C18, continuous NT for 18 months after chiseling; C12, continuous NT for 12 months after chiseling; C6, continuous NT for 6 months after chiseling; C0, NT in newly chiseling soil; Control, continuous NT without chiseling. Average values followed by the same letter horizontally, do not differ among themselves regarding the Tukey test $(\mathrm{p}<0.05)$. et al., 2009). According to Melero et al. (2011) the mechanical practices to mitigate soil compaction under NT promote decrease on soil organic matter. However, in our study no decrease on soil organic carbon content was observed due to the soil chiseling. Thus, the decrease in soil aggregate size, in the 0.07 to $0.20 \mathrm{~m}$ layer (Table 3), was only due to the effect of mechanical action of the shanks of chisel plow on the soil structure.

The shanks of chisel plow, during the soil chiseling operation, are expected not to disturb the soil structure as in the preparation with plow and harrow. The results obtained in this study, however, indicate that in the soil compacted layer ( 0.07 to $0.20 \mathrm{~m}$ ), in areas under NT, mechanical chiseling breaks the soil structure, disaggregating it. The hypothesis that soil chiseling in NT decreases soil aggregate stability and soil aggregate size, even if rejected for the surface soil layer, was confirmed for the 0.07 to 0.20 m layer. Colonego and Rosolem (2008) also observed that in a clayey soil, the shanks of chisel plow disaggregating action was higher in the subsurface layer in comparison with the surface layer, in areas under NT.

Plant root development, favored in the 0.07 to $0.17 \mathrm{~m}$ layer due to the soil chiseling operation, can be said to have promoted increase in the size and stability of soil aggregates (Martins et al., 2009), counteracting the negative effect of the shanks of chisel plow action observed in the first crop after this practice had been carried out, improving the percentage of aggregates larger than $2 \mathrm{~mm}$ in this layer. The positive effect of roots in the clayey soil aggregation state was also mentioned by Garcia and Rosolem (2010), Guedes Filho et al. (2013) and Silva et al. (2014). However, the effect of chiseling on soil physical properties and, consequently, on the corn plant root development, expired after short term. The effect on root system is only observed in the first crop after chiseling and only in the percentage of aggregates larger than $2 \mathrm{~mm}$, which became the same as the percentage of aggregates larger than $2 \mathrm{~mm}$ observed in the soil under continuous NT, six months after soil mechanical chiseling (C6) (Table 3 and Fig. 2).

According to our study, the effect of soil chiseling on soil physical improvement, in the 0.07 to 0.17 m layer, persists only in the first crops after operation. This indicates that soil chiseling might provide only mechanical effects, without representing effective improvement to the soil structure. This can be stated considering that the soil aggregation condition after three crops the soil was chiseled and the soil under continuous NT was similar. Moreover, the soil bulk density, indicative of its physical condition, and plant root development, did not have significant correlation with the soil aggregation parameters in this layer (Fig. 3b, c, d and e).

A root development increase restricted only to the first crops after soil chiseling (Table 5) is not enough to promote soil carbon accumulation and changes in the soil wet aggregation state under NT (Six et al., 2002). According to Abdollahi et al. (2014), increase in soil organic carbon levels can only be observed in the long-term. Most of the studies that point to improvement in the soil structure upon the use of covering plants cropping are based on long-term experiments (Eynard et al., 2004; Garcia et al., 2013; Silva et al., 2014). The carbon continuous flow leads to the humification of organic compounds and associations of carbon with aggregates and soil particles, which is, therefore, responsible for the formation of stable organic mineral complexes (Golchin et al., 1994).

The results of this study revealed that soil mechanical chiseling, as a technique to mitigate soil compaction in clayey soils under NT, provides only short-term effects, without contributing with long lasting improvement of the soil structure. The adoption of such a technique as a common practice, in itself, might become an obstacle regarding the conduction of NT as a management system, including the whole of its principles: species diversification via rotation, succession and intercropping; soil mobilization only at the sowing line; reduction or suppression of the time interval between the harvesting and the next sowing; and maintenance of crop residues on the soil surface, among others (Derpsch et al., 2010). The NT system conducted under the principles mentioned above can provide sustainability to the productive agriculture systems, in the medium and 

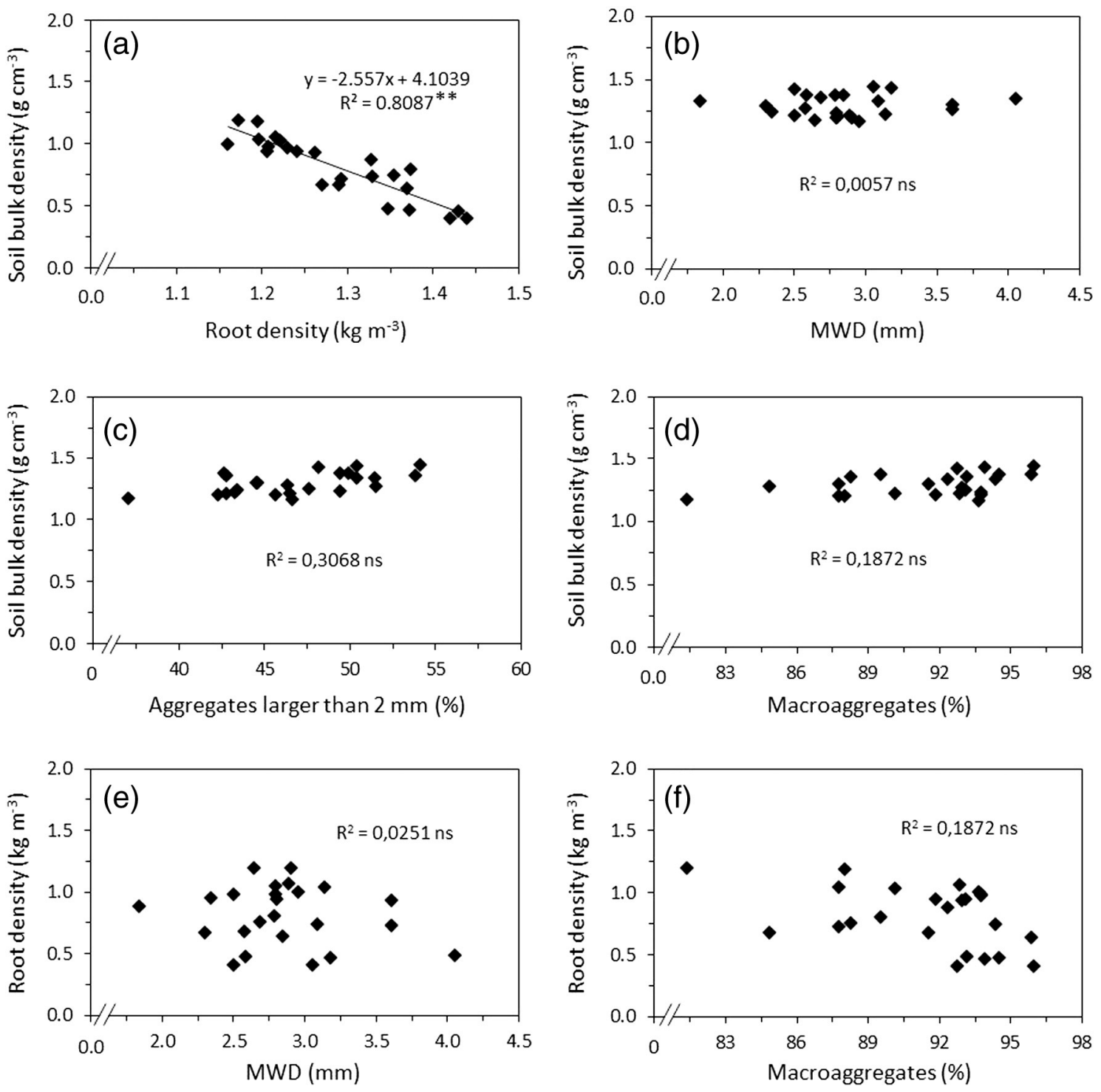

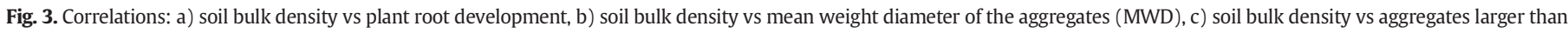

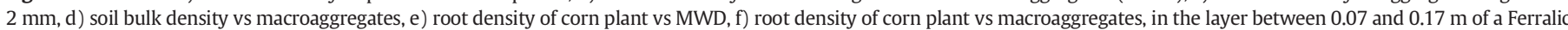
Nitisol (Rhodic) under no till. ns is not significant and ${ }^{* *}$ is significant to 0.01 .

long-term (Lal et al., 1999; Derpsch, 2004; Garcia et al., 2013) when compared with soil submitted to intermittent mechanical chiseling (Derpsch et al., 1986; Cavalieri et al., 2009; Franchini et al., 2012; Silva et al., 2014). Besides that, there is also evidence that the soil chiseling makes the soil more vulnerable to further compaction through the machinery traffic (Hamza and Anderson, 2005), depending on the subsequent cumulative rainfall (Busscher et al., 2002; Silva et al., 2012).

\section{Conclusions}

Our results showed that: i) mechanical chiseling of clayey soil under NT, in humid subtropical climate region, does not affect soil organic carbon content in the profile from 0 to $0.30 \mathrm{~m}$ depth; ii) mechanical chiseling of clayey soil under NT decreases the size and stability of soil aggregates, in the layer 0.07 to $0.17 \mathrm{~m}$, in the first six months after this practice; iii) the positive effects promoted by soil mechanical chiseling on soil physical attributes (penetration resistance, macroporosity and bulk density) and root development (root density) expired three crops after this operation; iv) root development in depth, intensified in the first crops after mechanical chiseling, is not enough to promote improvement in the soil aggregation state in the compacted sub-superficial soil layer ( 0.07 to $0.17 \mathrm{~m})$ in areas under NT; and v) mechanical chiseling of clayey soil under NT does not promote effective and long lasting improvements in the soil structure, in humid sub-tropical climate region.

\section{Acknowledgments}

We wish to express thanks to the Brazilian Research Council (CNPq) (Process number 382783/2014-0) and to the Brazilian Federal Agency for Support and Evaluation of Graduate Education (CAPES) for the scholarships and funding. Our gratitude is also expressed to the Brazilian Agricultural Research Corporation (EMBRAPA) for field support.

\section{References}

Abdollahi, L., Schjønning, P., Elmholt, S., Munkholm, L.J., 2014. The effects of organic matter application and intensive tillage and traffic on soil structure formation and stability. Soil Tillage Res. 136, 28-37.

Adl, S.M., Coleman, D.C., Read, F., 2005. Slow recovery of soil biodiversity in sandy loam soils of Georgia after 25 years of no-tillage management. Agric. Ecosyst. Environ. 114, 323-334.

Al-Kaisi, M.M., Yin, X., 2005. Tillage and crop residue effects on soil carbon and carbon dioxide emission in corn-soybean rotations. Soil Sci. Soc. Am. J. 34, 437-445. 
Babujia, L.C., Hungria, M., Franchini, J.C., Brookes, P.C., 2010. Microbial biomass and activity at various soil depths in a Brazilian oxisol after two decades of no-tillage and conventional tillage. Soil Biol. Biochem. 42, 2174-2181.

Batey, T., McKenzie, D.C., 2006. Soil compaction: identification directly in the field. Soil Use Manag. 22, 123-131.

Baver, L.D., Gardner, W.H., Gardener, W.R., 1973. Fisica de suelos (México, 529 pp.).

Bertolini, E.V., Gamero, C.A., 2010. Energy demand and corn yield with fertilizer application before sowing in two soil tillage systems. Energy Agric. J. 25, 1-23.

Bohm, W., 1979. Methods of Studying Root Systems. Springer-Verlag, New York.

Busscher, W.J., Bauer, P.J., Frederick, J.R., 2002. Recompaction of a coastal loamy sand after deep tillage as a function of subsequent cumulative rainfall. Soil Tillage Res. 68, 49-57.

Buttery, B.R., Tan, C.S., Drury, C.F., Park, S.J., Armstrong, R.J., Park, K.Y., 1998. The effects of soil compaction, soil moisture and soil type on growth and nodulation of soybean and common bean. Can. J. Plant Sci. 78, 571-576.

Cavalieri, K.M.V., Silva, A.P., Tormena, C.A., Leão, T.P., Dexter, A.R., Hakansson, I., 2009. Long-term effects of no-tillage on dynamic soil physical properties in a Rhodic Ferrasol in Parana, Brazil. Soil Tillage Res. 103, 158-164.

Colonego, J.C., Rosolem, C.A., 2008. Soil aggregate stability after management with crop rotation and chiseling. Braz. J. Soil Sci. 32, 1399-1407.

Colonego, J.C., Rosolem, C.A., 2010. Soybean root growth and yield in rotation with cover crops under chiseling and no-till. Eur. J. Agron. 33, 242-249.

Derpsch, R., 2004. History of crop production with and without tillage. Leading edge. J. No-Till Agric. 3, 150-154

Derpsch, R., Sidiras, N., Roth, C.H., 1986. Results of studies made from 1977 to 1984 to control erosion by cover crops and no-tillage techniques in Paraná, Brazil. Soil Tillage Res. 8, 253-263.

Derpsch, R., Friedrich, T., Kassam, A., Hongwen, L., 2010. Current status of adoption of notill farming in the world and some of its main benefits. Int. J. Agric. Biol. Eng 3, 1-26.

Drescher, M.S., 2011. Residual Effect of Mechanical Interventions for Decompaction of Soil Managed Under No-till (MSc Dissertation), Universidade Federal de Santa Maria, Santa Maria (81 pp.).

Embrapa, 2011. Manual de métodos de análises de solos. 2nd ed. Embrapa Solos, Rio de Janeiro (230 pp.).

Evans, S.D., Lindstrom, M.J., Voorhees, W.B., Moncrief, J.F., Nelson, G.A., 1996. Effect of subsoiling and subsequent tillage on soil bulk density, soil moisture, and corn yield. Soil Tillage Res. 38, 35-46.

Eynard, A., Schumacher, T.E., Lindstrom, M.J., Malo, D.D., 2004. Aggregate sizes and stability in cultivated South Dakota prairie Ustolls and Usterts. Soil Sci. Soc. Am. J. 68, 1360-1365.

Fabrizzi, K.P., Rice, C.W., Amado, T.J.C., Fiorin, J., Barbagelata, P., Melchiori, R., 2009. Protection of soil organic $\mathrm{C}$ and $\mathrm{N}$ in temperate and tropical soils: effect of native and agroecosystems. Biogeochemistry 92, 129-143.

Franchini, J.C., Debiasi, H., Balbinot Jr., A.A., Tonon, B.C., Farias, J.R.B., Oliveira, M.C.N., Torres, E., 2012. Evolution of crop yields in different tillage and cropping systems over two decades in southern Brazil. Field Crop Res. 137, 178-185.

Garcia, R.A., Rosolem, C.A., 2010. Aggregates in a Rhodic Ferralsol under no-tillage and crop rotation. Braz. J. Agric. Res. 45, 1489-1498.

Garcia, R.A., Li, Y., Rosolem, A.C., 2013. Soil organic matter and physical attributes affected by crop rotation under no-till. Soil Sci. Soc. Am. J. 77, 1724-1731.

Gee, G.W., Or, D., 2002. Particle-size analysis. In: Dane, J.H., Topp, G.C. (Eds.), Methods of Soil Analysis Madison. Soil Science Society of America, Madison, Wisconsin, USA, pp. 255-293.

Golchin, A., Oades, J.M., Skjemstad, J.O., Clarke, P., 1994. Soil structure and carbon cycle. Aust. J. Soil Res. 32, 1043-1068

Grossman, R.B., Reinsch, T.G., 2002. Bulk density and linear extensibility. In: Dane, J.H., Topp, G.C. (Eds.), Methods of Soil Analysis. Soil Science Society of America, Madison, Wisconsin, USA, pp. 207-210.
Guedes Filho, O., Silva, A.P., Giarola, N.F.B., Tormena, C.A., 2013. Structural properties of the soil seedbed submitted to mechanical and biological chiseling under no-tillage. Geoderma 204-205, 94-101.

Hamza, M.A., Anderson, W.K., 2005. Soil compaction in cropping systems: a review of the nature, causes and possible solutions. Soil Tillage Res. 82, 121-145.

Kemper, W.D., Chepil, W.S., 1965. Size distribution of aggregation. In: Black, C.A. (Ed.), Methods of Soil Analysis. American Society of Agronomy, Madison, pp. 499-510.

Lal, R., Follett, R.F., Kimble, J., Cole, C.V., 1999. Managing US cropland to sequester carbon in soil. J. Soil Water Conserv. 54, 374-381.

Martins, M.R., Corá, J.E., Jorge, R.F., Marcelo, A.V., 2009. Crop type influences soil aggregation and organic matter under no-tillage. Soil Tillage Res. 104, 22-29.

Melero, S., Panettieri, M., Madejón, E., Gómez Macpherson, H., Moreno, F., Murillo, J.M., 2011. Implementation of chiselling and mould board ploughing in soil after 8 years of no-till management in SW, Spain: effect on soil quality. Soil Tillage Res. 112, 107-113.

Nunes, M.R., Pauletto, E.A., Denardin, J.E., Faganello, A., Pinto, L.F.S., Scheunemann, T., 2014. Persistence of chiseling effects on the compaction of a Nitisol under no-till in a humid subtropical region. Braz. J. Agric. Res. 49, 531-539.

Nunes, M.R., Denardin, J.E., Pauletto, E.A., Faganello, A., Pinto, L.F.S., 2015. Mitigation of clayey soil compaction managed under no-tillage. Soil Tillage Res. 148, 119-126.

Portella, C.M.R., Guimarães, M.F., Feller, C., Fonseca, I.C.B., Tavares Filho, J.T., 2012. Soil aggregation under different management systems. Braz. J. Soil Sci. 36, 1868-1877.

Putte, A.V., Govers, G., Diels, J., Gillijns, K., Demuzere, M., 2010. Assessing the effect of soil tillage on crop growth: a meta-regression analysis on European crop yields under conservation agriculture. Eur. J. Agron. 33, 231-241.

Reichert, J.M., Suzuki, L.E.A.S., Reinert, D.J., Horn, R., Hakansson, I., 2009. Reference bulk density and critical degree-of-compactness for no-till crop production in subtropical highly weathered soils. Soil Tillage Res. 102, 242-254.

Ritchie, S.W., Hanway, J.J., 1993. How a Corn Plant Develops. Iowa University of Science and Technology, Cooperative Extension Service, Ames.

Santos, N.Z., Dieckow, J., Bayer, C., Molin, R., Favaretto, N., Pauletti, V., Piva, J.T., 2011. Forages, cover crops and related shoot and root additions in no-till rotations to $C$ sequestration in a subtropical Ferralsol. Soil Tillage Res. 111, 208-218.

Shaver, T.M., Peterson, G.A., Sherrod, L.A., 2003. Cropping intensification in dryland systems improves soil physical properties: regression relations. Geoderma 116, $149-164$

Silva, S.G.C., Silva, A.P., Giarola, N.F.B., Tormena, C.A., Sá, J.C.M., 2012. Temporary effect of chiseling on the compaction of a Rhodic Hapludox under no-tillage. Braz. J. Soil Sci. 36, 547-555.

Silva, A.P., Babujia, L.C., Franchini, J.C., Ralisch, R., Hungria, M., Guimarães, M.F., 2014. Soil structure and its influence on microbial biomass in different soil and crop management systems. Soil Tillage Res. 142, 42-53.

Six, J., Feller, C., Denef, K., Ogle, S.M., Sá, J.C.M., Albrechi, A., 2002. Soil organic matter biota and aggregation in temperate and tropical soils - effects of no-tillage. Agronomie 22, $755-775$.

Soane, B.D., Ball, B.C., Arvidsson, J., Basch, G., Moreno, F., Roger-Estrade, J., 2012. No-till in northern, western and southwestern Europe: a review of problems and opportunities for crop production and the environment. Soil Tillage Res. 118, 66-87.

Tisdall, J.M., Oades, J.M., 1982. Organic matter and water stable aggregates in soil. J. Soil Sci. 33, 141-163.

Trasar-Cepeda, C., Leiros, M.C., Seoane, S., Gil-Sotres, F., 2008. Biochemical properties of soils under crop rotation. Appl. Soil Ecol. 39, 133-143.

United States Departmentof Agriculture (USDA), 2012. Soil Taxonomy. USDA-NRCS, Washington, DC, USA

Visser, S., Parkinson, D., 1992. Soil biological criteria as indicators of soil quality: soil microorganisms. Am. J. Altern. Agric. 7, 33-37.

Yoder, R.A., 1936. Direct method of aggregate analysis of soil and a study of the physical nature of erosion losses. J. Am. Soc. Agron. 28, 337-351. 